Egyptian Journal of Aquatic Biology \& Fisheries

Zoology Department, Faculty of Science,

Ain Shams University, Cairo, Egypt.

ISSN $1110-6131$

Vol. 25(3): $411-420$ (2021)

www.ejabf.journals.ekb.eg

\title{
Breeding Ecology of the Graceful Prinia (Prinia gracilis) at Akiad Pond, Sharkia Governorate, Egypt.
}

\author{
Kareem M. Soliman (1*); Hany A. A. Ahmed (1); Hussein M. Rashad (2); \\ Wael M. Shohdi (3); Mohamed A. Issa (4) \\ ${ }^{1}$ Department of Zoology, Faculty of Science, Ain Shams University, Cairo, Egypt \\ ${ }^{2}$ Ashtom El-Gamil Protectorate, Egyptian Environmental Agency, Egypt. \\ 3 Independent Consultant Ecologist, Cairo, Egypt. \\ ${ }^{4}$ Plant Protection Research Institute, Agricultural Research Center, Giza, Egypt. \\ *Corresponding author: dr kariemsoliman@yahoo.com
}

\begin{abstract}
ARTICLE INFO
Article History:

Accepted: June 3, 2021

Online: June 7, 2021

Keywords:

Akiad Pond,

Prinia gracilis,

Clutch size,

Incubation period,

Hatching,

Fledging,

breeding success.
\end{abstract}

Received: May 20, 2021

\begin{abstract}
Characterizing the breeding ecology of birds is important for understanding their population dynamics. One of the most common small resident birds in Egypt that acts as a biocontrol agent of insects is Graceful Prinia (Prinia gracilis). Despite its importance, there are few studies on its breeding ecology in Egypt. Accordingly, this study is the first in investigating the population density and the breeding ecology (including the clutch size, incubation period, fledging period, hatching success, fledging success, and breeding success) of $P$. gracilis at Akiad Pond, Sharkia Governorate, Egypt during 2019. Results of the current study showed that $P$. gracilis followed the pattern spring $>$ summer $>$ autumn $>$ winter in abundance during 2019. Regarding its breeding ecology, $P$. gracilis laid from 2 to 5 eggs/clutch with an average of $3.75 \pm 0.25$ eggs. 42 young hatched from 60 eggs recording $70 \%$ hatching success rate throughout the study period at Akiad pond. Moreover, about 37 chicks fledged and 5 died recording $88 \%$ fledging success rate. Clutches of two and three eggs had higher fledging success than the other clutches because of the inability of parents to meet the basic feeding needs in large broods. The incubation period was $12.56 \pm 0.20$ days/nest to produce 2.6 hatchlings/nest, while the fledgling period was $14.62 \pm 0.27$ days/nest to produce 2.315 young fledged/nest. The breeding success was $61.6 \%$ in relation to the number of eggs laid. The main threats to the bird life are human activities (as burning for regrowth, cattle grazing, fishing and in some way desiccation to some patches around the pond in summer) that destroy its food and nests requirements.
\end{abstract}

\section{INTRODUCTION}

The fundamental breeding ecology of about $67 \%$ bird species is poorly understood despite being the building block in bird's life history (Xiao et al., 2017). Regarding Passeriformes, less than $7 \%$ of the researches conducted on passerines include breeding information (Pienaar $\boldsymbol{e t}$ al., 2013). 
The Graceful Prinia (Prinia gracilis), a small polytypic warbler species belonging to family Cisticolidae and order Passeriformes, is one of the resident passerines suffering shortage of information on its breeding ecology in Egypt. The only published article on the breeding biology of P. gracilis in Egypt was by Simmons (1954) in Fayid, lower Egypt during the breeding season 1949/1950. Since then, no studies on its breeding ecology in Egypt were conducted despite their abundance and wide distribution.

To the best of our knowledge, Zduniak and Yosef (2004) studied the seasonal abundance and biometric differences between sex and age groups of $P$. gracilis in Israel. Kiat and Izhaki (2015) analyzed the timing, sequence, extent and duration of post-juvenile moult in $P$. gracilis in Israel. Sheta (2019) examined the breeding habitats of $P$. gracilis in Lake Burullus, Egypt, during winter and spring 2018.

Considering the Egyptian biodiversity strategy and action plan (2015-2030) for conserving wildlife, as well as, the recommendations of Bird Life International (2015) and International Union for Conservation of Nature (IUCN) (2019), up-to-date monitoring programs on Graceful Prinia ecology became essential to inform conservation measures. Accordingly, this paper aimed at exploring data about the population density and the breeding ecology (including the clutch size, incubation period, fledging period, hatching success, fledging success, and breeding success) of Graceful Prinia ( $P$. gracilis) at Akiad Pond, Sharkia Governorate, Egypt during 2019.

\section{MATERIALS AND METHODS}

\section{Study area:}

The study area viz, Akiad Pond lies in Al-Azzazi Village, Faqous District, Sharkia Governorate, Egypt. The pond covers an area of 2000 feddan. An island covering an area of about 360 feddan divides the water in the pond into two parts. The northern part is characterized by freshwater whereas the southern is salty. The island is characterized by large reed beds which form a very good habitat for bird breeding as Typha domingensis (Pers.) Poir. ex Steud., Phragmites australis (Cav.) Trin. ex Steud., Juncus acutus L., Arthrocnemum macrostachyum (Moric.) K. Koch., Halocneum strobilaceum (Pall.) M. Bieb. (Boulos, 1999; 2000; 2005 a \& b, 2009). The area is characterized by a moderate warm weather during winter.

The pond was surveyed to determine the most suitable areas for the nesting of $P$. gracilis within the area around the pond. Four points were chosen based on the plant cover and possible nesting habitats (Figure 1). 


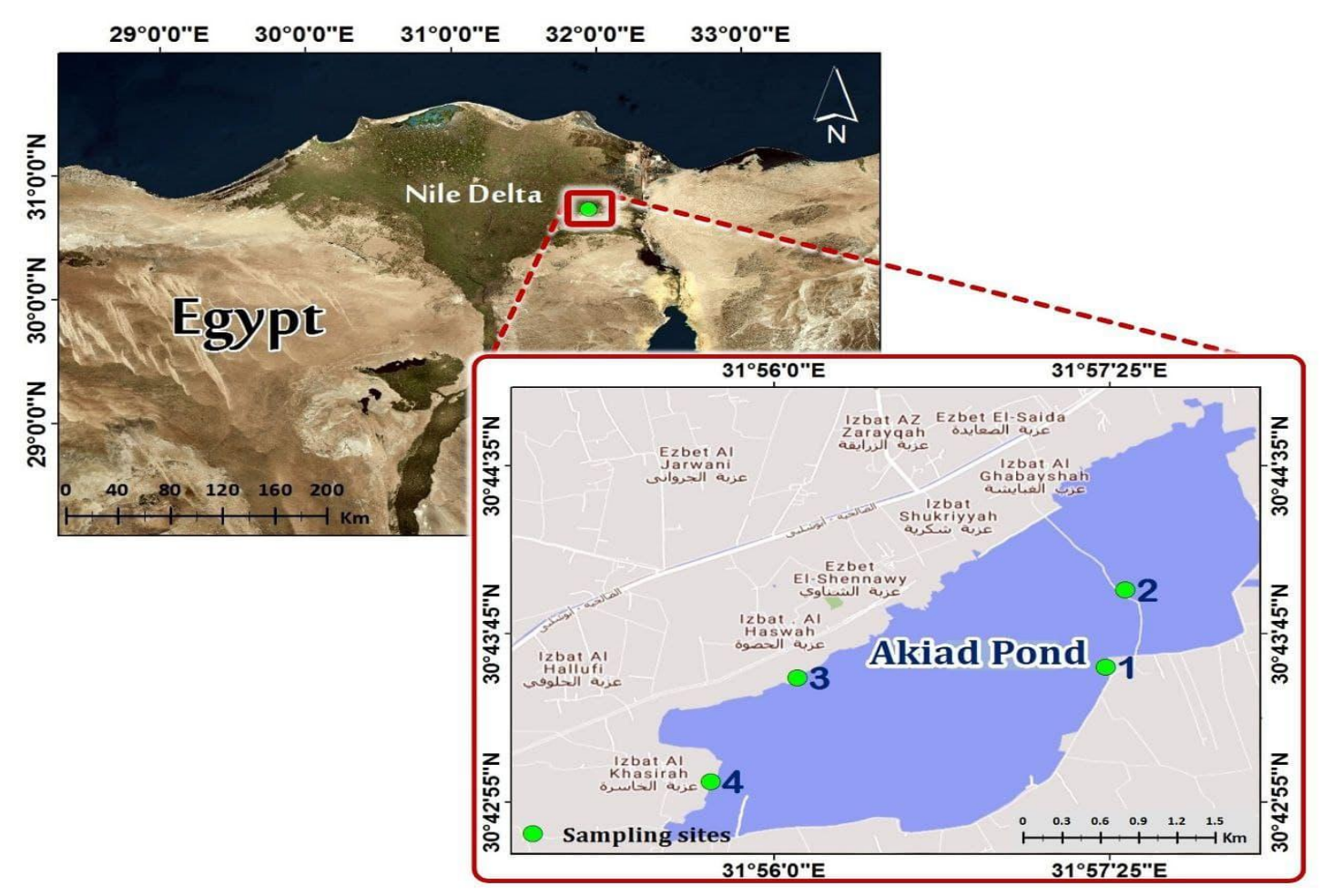

'Figure 1. Google Earth satellite image showing the location of the four surveyed points at Akiad Pond, Sharkia Governorate, Egypt.

\section{Field methods:}

\section{Counting:}

The study was carried out from January to December 2019. Field data were obtained using the point counts method, which is suitable for studying highly visible and vocal bird species as Graceful Prinia in a wide variety of habitats (Bibby et al., 2000). Bird counts were performed (from 6 to 8 am during winter and spring and from 5 to 7 am during summer and autumn) once monthly with binoculars $(10 \times 50)$ from a fixed raising position within a circle of $40 \mathrm{~m}$ radius (about $5024 \mathrm{~m}^{2}$ at each point). The days selected for counting were clear with no winds and rain conditions. Species identity was done using Collins Bird Guide (Svensson et al., 2009).

\section{Some breeding aspects and breeding parameters associated with $\boldsymbol{P}$. gracilis:}

We started searching weekly for nests during February then every two to three days in March, April, May, and June 2019. Nests were numbered and checked for eggs hatching and nestlings fledging time, to determine the first egg lying date, clutch size, hatching period, number of fledging, and fledgling period (Humple and Burnett, 2010).

The number of eggs laid in a nest was defined as clutch size, while the fledging period is the time between the day of the first egg hatching to the day where the bird holds true feather and leaves the nest (Jehel et al., 2004). 
To examine the breeding ecology of $P$. gracilis, the study estimated three reproductive rates namely; hatching success rate, fledgling success rate, and the breeding success rate. The hatching success is defined as the number of eggs hatched divided by the total number of eggs laid, whereas, the fledgling success is defined as the number of chicks fledged divided by the total number of hatched eggs (Metallaoui et al., 2019). The breeding (=egg) success is the proportion of total number of chicks fledged to the total number of eggs (Awais et al., 2015).

Hatching success $\%=($ Number of hatched eggs $/$ Total number of eggs $) * 100$

Fledgling success $\%=($ Number of fledgling / Total number of hatched eggs $) * 100$

Breeding (or Egg) success \% $=$ (Number of fledglings $/$ Total no. of eggs) $* 100$

\section{Statistical analysis:}

One-way analysis of variance (ANOVA) was used to assess the significant difference between the different points. Difference is significant when $\mathrm{p}<0.05$. Analysis of data was performed using SPSS software version 16 (Levesque, 2005).

\section{RESULTS}

\section{Population density of $\boldsymbol{P}$. gracilis:}

In the present study, a total of 666 individual was monitored during 2019 at the four selected localities in Akiad pond, Sharkia Governorate. During 2017, Issa (2019) observed about 461 individual of $P$. gracilis in Sharkia Governorate.

Results of the population density of $P$. gracilis varied from 34 to 120 with an average $( \pm$ SE) of $55.5( \pm 13.46)$ per one hectare in Akiad pond, Sharkia Governorate during 2019 (Table 1). P. gracilis followed the pattern spring > summer > autumn > winter in abundance during 2019 (Figure 2). The highest densities were recorded in spring (April and May with 120 and 88 individuals, respectively). On the other hand, winter recorded the lowest density (Table 1; Figure 2). Similar results were reported in Israel by Zduniak and Yosef (2004). Issa (2019) attributed the variations in population density to the availability of the essential life requirements (as food, water, and shelter) and to the weather conditions during different months of the year. No significant difference was recorded between the four localities at Akiad pond in the current study (Table 1).

\section{Breeding Ecology of $\boldsymbol{P}$. gracilis:}

In the present study, the breeding period started in March $13^{\text {th }}, 2019$. This finding is consistent with Cramp (1998) who reported that $P$. gracilis begins its breeding season in March and ends in late July, rarely in August. However, Shirihai (1996) reported that P. gracilis breeding season lasts from late January to September. Ryan (2006) mentioned that egg-laying differs from place to another. In Egypt, Israel, and Iraq egg-laying occurs from February to July, while in Pakistan and India from February to October (Ryan, 2006). 
Table 1: Population density of the Graceful Prinia (P. gracilis) at Akiad Pond.

\begin{tabular}{|c|c|c|c|c|c|c|}
\hline \multirow[b]{2}{*}{ Months } & \multicolumn{4}{|c|}{ Points } & \multirow[b]{2}{*}{ Total } & \multirow[b]{2}{*}{$\mathrm{M} \pm \mathrm{SE}$} \\
\hline & $1^{\text {st }}$ & $2^{\text {nd }}$ & $3^{\text {rd }}$ & $4^{\text {th }}$ & & \\
\hline Jan & 10 & 8 & 9 & 7 & 34 & $8.5 \pm 0.64$ \\
\hline Feb & 11 & 8 & 10 & 11 & 40 & $10 \pm 0.71$ \\
\hline Mar & 9 & 10 & 7 & 8 & 34 & $8.5 \pm 0.64$ \\
\hline Apr & 37 & 30 & 33 & 20 & 120 & $30 \pm 3.63$ \\
\hline May & 28 & 24 & 19 & 17 & 88 & $22 \pm 2.48$ \\
\hline Jun & 18 & 13 & 16 & 11 & 58 & $14.5 \pm 1.55$ \\
\hline Jul & 26 & 20 & 19 & 15 & 80 & $20 \pm 2.27$ \\
\hline Aug & 21 & 16 & 8 & 7 & 52 & $13 \pm 3.34$ \\
\hline Sep & 14 & 11 & 9 & 8 & 42 & $10.5 \pm 1.32$ \\
\hline Oct & 13 & 12 & 7 & 6 & 38 & $9.5 \pm 1.75$ \\
\hline Nov & 13 & 10 & 10 & 9 & 42 & $10.5 \pm 0.87$ \\
\hline Dec & 10 & 11 & 8 & 9 & 38 & $9.5 \pm 0.64$ \\
\hline Total & 210 & 173 & 155 & 128 & 666 & --- \\
\hline $\mathrm{M} \pm \mathrm{SE}$ & $17.5 \pm 4.41$ & $14.42 \pm 3.44$ & $12.92 \pm 3.85$ & $10.67 \pm 2.21$ & $55.5 \pm 13.46$ & --- \\
\hline F-value & \multicolumn{4}{|c|}{1.93344} & -- & -- \\
\hline P-value & \multicolumn{4}{|c|}{0.138084} & -- & -- \\
\hline Significance & \multicolumn{4}{|c|}{ NS } & -- & -- \\
\hline
\end{tabular}

NS: refers to no significant; $\mathrm{M} \pm \mathrm{SE}$ : mean \pm standard error.

The present study observed that $P$. gracilis built their nests in Juncus acutus plants around the pond. This observation was consistent with Baha El Din (1999) who mentioned that $P$. gracilis inhabited low vegetation. Sheta (2019) examined the breeding habitats of $P$. gracilis in Lake Burullus, Egypt, during winter and spring 2018. She noted the presence of $P$. gracilis in three different habitats (open water, islets, and reed beds) with significant affinities $(\mathrm{P}<0.01)$ to islands habitat. $P$. gracilis is monogamous with the pairs defending territories throughout the year (Kiat and Izhaki, 2015). The male constructs the nest and the female assists by lining the cup and the incubation is carried out by males and females (Shirihai, 1996).

The study recorded clutch sizes with 2-5 eggs for $P$. gracilis at Akiad pond. Six of 16 clutches had four eggs (37.5\%), four had three eggs (25\%), four had five eggs (25\%), and only two had two eggs (12.5\%) (Table 2), resulting in an average clutch size of $3.75 \pm 0.25$ eggs. Simmons (1954) recorded (3-5 eggs) for other populations of this species in Fayid, Lower Egypt. Paz (1987) mentioned that $P$. gracilis can lay up to five clutches. Lack (1947) attributed the difference in number of clutches to the food availability and to the length of the day that can 
spur the growth of the gonads. He noted that the number of eggs laid reflects the bird physical condition.

Table (2) reveals that the highest hatching success rate was recorded in the nests of two eggs $(75 \%)$ while the lowest was in the nests of three eggs $(66.67 \%)$. However, the clutches of two and three eggs had higher fledging success $(100 \%)$ than the other clutches. The highest breeding success rate was also recorded in the two egg clutches (75\%), whereas the clutch with five eggs was the lowest $(55 \%)$. Issa (2019) attributed this finding to the inability of parents to meet the basic feeding needs in large broods; accordingly only strong individuals in large broods will survive. Indeed, the study encountered a lot of human activities (as burning for regrowth, cattle grazing, fishing, and in some way desiccation to some patches around the pond in summer) that destroy the bird's food and nests requirements.

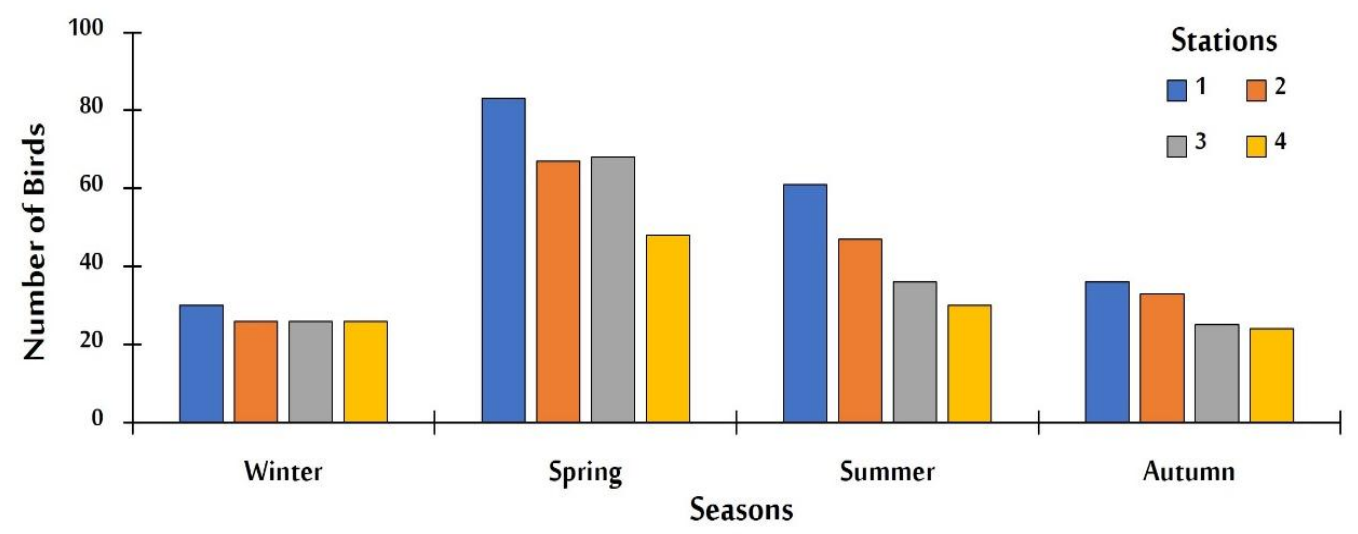

Figure 2: The seasonal number of $P$. gracilis in each station during the study period 2019 at Akiad Pond.

Overall, in the 16 observed nests, 42 young hatched from 60 eggs recording $70 \%$ hatching success rate throughout the study period at Akiad pond. Moreover, about 37 chicks fledged and 5 died recording $88 \%$ fledging success rate. The clutch size was 3.75 \pm 0.25 eggs/nest (range: $2-5$, $\mathrm{n}=16$ ), incubated for $12.56 \pm 0.20$ days to produce 2.6 hatchlings/nest. The breeding success rate was $61.6 \%$ in relation to the number of eggs laid, while the productivity was 2.315 young fledged/nest (Table 2).

Table (3) compares the results of the reproductive traits of $P$. gracilis in the present study with the available previous studies on the same species. It was obvious that the current results of the incubation period resembled those reported by Simmons (1954) and Shirihai (1996). On the other hand, the fledgling period (14.62 days) recorded in our study was slightly higher than those recorded by Simmons (1954) and Shirihai (1996). Hatching success of 70\% was recorded in our study and it was lower than that was recorded by Simmons (1954) (78\%). Breeding success depending mainly on the proportion of nests which are subjected to predation and starving (Newton, 1964), in our study it was higher (61.67\%) than those (41\%) reported Simmons 
(1954), probably because no natural predators were observed and the surrounded areas were suitable with a good variability and availability of food supplies.

Table 2: Breeding aspects of P. gracilis at Akiad Pond

\begin{tabular}{lccccc}
\hline \multirow{2}{*}{ Parameters } & \multicolumn{4}{c}{ Clutch size } & Total \\
\cline { 2 - 5 } & $\mathbf{2}$ & $\mathbf{3}$ & $\mathbf{4}$ & $\mathbf{5}$ & 16 \\
\hline Number of nests & 2 & 4 & 6 & 4 & 60 \\
Total number of eggs & 4 & 12 & 24 & 20 & 42 \\
Number of hatchlings & 3 & 8 & 17 & 14 & 37 \\
Number of fledglings & 3 & 8 & 15 & 11 & 70 \\
Hatching success \% & 75 & 66.67 & 70.83 & 70 & 2.625 \\
Hatchling/nest & 1.5 & 2 & 2.83 & 3.5 & 88.09 \\
Fledging success \% & 100 & 100 & 88.23 & 78.57 & 2.3125 \\
Fledglings/nest & 1.5 & 2 & 2.5 & 2.75 & 61.67 \\
Breeding (=Egg) success \% & 75 & 66.67 & 62.5 & 55 & \\
Incubation period \pm SE (days) & & & & $12.56 \pm 0.2$ & \\
Fledgling period \pm SE (days) & & & & $14.62 \pm 0.27$ &
\end{tabular}

SE: Standard Error; \%: Percentage

Table 3. Reproductive traits of Prinia gracilis in the current study in comparison with other studies.

\begin{tabular}{|c|c|c|c|c|c|}
\hline Locality & $\begin{array}{c}\text { Incubation Period } \\
\text { (days) }\end{array}$ & Fledging Period (days) & Hatching Success & $\begin{array}{l}\text { Breeding } \\
\text { Success }\end{array}$ & Reference \\
\hline Akiad pond, Egypt & $12.56( \pm 0.2)$ & $14.62( \pm 0.27)$ & $70 \%$ & $61.67 \%$ & Present study \\
\hline Fayid, Egypt & $11-13( \pm 1)$ & 13-14 ( \pm 18 hrs) & $78 \%$ & $41 \%$ & [1] \\
\hline Israel & $12-13$ & $10-15$ & & & [2] \\
\hline
\end{tabular}

[1]: Simmons (1954); [2]: Shirihai (1996)

\section{CONCLUSION}

The current study examined the population density and breeding ecology of $P$. gracilis at Akiad Pond, Sharkia Governorate, Egypt. Results showed that the clutches of two and three eggs had higher fledging success than the other clutches may be because of the inability of parents to meet the basic feeding needs in large broods. Moreover, the overall breeding success rate of the bird was $61.67 \%$. The bird can be facing a true threat that may end in its vanishing from the pond ecosystem due to human activities (as burning for regrowth, cattle grazing, fishing and in some 
way desiccation to some patches around the pond in summer) that destroy its food and nests requirements.

\section{RECOMMENDATION}

There's an urgent need for more studies about $P$. gracilis especially in agricultural habitats with awareness programs for local people about its benefits and ways of protection. $P$. gracilis feeds mainly on beetles and their larvae, caterpillars and adult lepidopterans, grasshoppers, flies, and spiders (Ryan, 2006), so it can be used as a potential biocontrol agent of insects.

\section{REFERENCES}

Awais, M.; Shabir, A.; Sajid, M.; Tariq, M. and Hanif, A. (2015). Breeding biology of the House crow Corvus splendens at Hazara University, Garden Campus, Mansehra, Pakistan. Podoces 10: 1-7.

Baha El Din, S. (1999). Directory of Important Bird Areas in Egypt. BirdLife International. The Palm Press. Cairo.

Bibby, C.J.; Brgess, N.D.; Hill, D.A. and Mustoe, S.H. (2000). Bird census techniques. Second edition. Academic Press, London.

Bird Life International (2015). European Red List of Birds. Office for Official Publications of the European Communities, Luxembourg.

Boulos, L. (1999). Flora of Egypt. vol. 1. Azollaceae- Oxalidaceae Al-Hadara Publishing, Cairo, Egypt. 419 pp.

Boulos, L. (2000). Flora of Egypt. vol. 2. - Verbenaceae - Boraginaceae. Al-Hadara Publishing, Cairo, Egypt. 352 pp.

Boulos, L. (2005a). Flora of Egypt. vol. 3. -Verbenaceae- Compositae Al-Hadara Publishing, Cairo, Egypt. 373 pp.

Boulos, L. (2005b). Flora of Egypt. vol. 4. -Alismataceae- Orchidaceae. Al-Hadara Publishing, Cairo, Egypt. 617 pp.

Boulos, L. (2009). Flora of Egypt Checklist. -Revised Annotated Edition. Al-Hadara Publishing, Cairo. Egypt. 410 pp.

Cramp, S. (1998). The Complete Birds of Western Palearctic on CD-ROM. Oxford Univ. Press. 
Humple, D.L. and Burnett, R.D. (2010). Nesting Ecology of Yellow Warblers (Dendroica petechia) in Montane Chaparral Habitat in the Northern Sierra Nevada. West. N. Am. Nat. 70: $355-363$.

Issa, M.A. (2019). Diversity and abundance of wild bird species' in two different habitats at Sharkia Governorate, Egypt. JOBAZ 80:34. https://doi.org/10.1186/s41936-019-0103-5.

IUCN (International Union for Conservation of Nature) (2019). The IUCN Red List of Threatened Species. Version 2019-3. Available at www.iucnredlist.org.

Jehle, G.; Yackel Adams, A.A.; Savidge, J.A. and Skagen, S.K. (2004). Nest survival estimation: a review of alternatives to the mayfield estimator. Condor 106: 472-484. http://dx.doi.org/10.1650/7411

Kiat, Y. and Izhaki, I. (2015). Post-juvenile moult in Graceful prinia (Prinia gracilis). Ringing \& Migration. https://doi.org/10.15468/39omei accessed via GBIF.

Lack, D. (1947). The significance of clutch size, parts 1 and 2. Ibis 89: 302-352.

Levesque, R. (2005). SPSS programming and data management: a guide for SPSS and SAS user, $2^{\text {nd }}$ Edition. United States of America.

Metallaoui, S.; Dziri, H.; Bousseheba, A.; Heddam, S. and Chenchouni, H. (2019). Breeding ecology of the cattle egret (Bubulcus ibis) in Guerbes-Sanhadja wetlands of Algeria. Regional studies in Marine Science 33, 2020, 100979. https://doi.org/10.1016/j.rsma.2019.100979.

Newton, I. (1964). The breeding biology of the Chaffinch. Bird study 11: 47-68. https://doi.org/10.1080/00063656409476059

Paz, U. (1987). The birds of Israel. Ministry of Defense Publ. Tel Aviv.

Pienaar, J.; Ilany, A.; Geffen, E. and Yom-Tov, Y. (2013). Macroevolution of life-history traits in passerine birds: adaptation and phylogenetic inertia. Ecol Lett 16: 571-576.

Ryan, P. (2006). Graceful Prinia (Prinia gracilis), Handbook of the Birds of the World. (J. del Hoyo, A. Elliott, J. Sargatal, D. A. Christie, and E. de Juana, Editors). - Lynx Edicions, Barcelona 11: 378492. ISBN 978-84-96553-06-4.

Sheta, B.M. (2019). Biodiversity and habitat use of wintering and breeding water birds in Burullus Lake, Egypt. Catrina 19: 47-54.

Shirihai, H. (1996). The Birds of Israel. Academic Press, London. 
Simmons, K. E. L. (1954). The behaviour and general biology of the Graceful Warbler Prinia gracilis. Ibis 96: 262-292. doi: 10.1111/j.1474-919X.1954.tb04128.x

Svensson, L.; Mullarney, K.; Zetterström, D. and Grant, P. J. (2009). Collins bird guide. Second edition. Harper Collins, London.

Xiao, H. ; Hu, Y. ; Lang, Z. ; Fang, B. ; Guo, W. ; Zhang Q et. al. (2017). How much do we know about the breeding biology of bird species in the world? J Avian Biol. 48: 513-8.

Zduniak, P. and Yosef, R. (2004). Seasonal biometric differences between sex and age groups of the Graceful Warbler Prinia gracilis at Eilat (Israel). Acta Ornithologica 39: 169-175. 